\title{
\#EdTechHub
}

Realising the potential of technology in education

\section{EdTech in Pakistan: A Rapid Scan}

Imdad Baloch and Abeba Taddese

EdTech Hub, https://edtechhub.org

Country Scan

2020-06-30

DOI: 10.5281/zenodo.3911655

For enquiries please email helpdesk@edtechhub.org

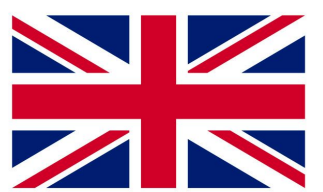




\section{About this document}

Recommended Baloch, I., and Taddese, A. (2020). EdTech in Pakistan: A Rapid Scan. (EdTech citation. Hub Country Scan). DOI: 10.5281/zenodo.3911655. Available from https://docs.edtechhub.org/lib/FIQDEKCl. Available under Creative Commons Attribution 4.0 International, https://creativecommons.org/licenses/by/4.0/.

Licence. Creative Commons Attribution 4.0 International https://creativecommons.org/licenses/by/4.0/.

You - dear readers - are free to share (copy and redistribute the material in any medium or format) and adapt (remix, transform, and build upon the material) for any purpose, even commercially. You must give appropriate credit, provide a link to the license, and indicate if changes were made. You may do so in any reasonable manner, but not in any way that suggests the licensor endorses you or your use.

\section{Creative \\ N/A}

\section{Commons}

Acknow-

ledgement

Identifiers. 2405685:FIQDEKCl; $10.5281 /$ zenodo.3911655

Internal use. g/document/d/1bmyusX5nV7svYeqrEUohEiOh6tHIF5cKyyQiyMiTo9c/ edit?ts=5ef7f633

Notes.

You can contact the EdTech Hub here: https://edtechhub.org/hello/

Reviewed by Mehjabeen Zameer, Education Advisor, DFID Pakistan 


\section{About this scan}

EdTech Hub country scans explore factors that enable and hinder the use of technology in education. This includes policies, government leadership, private-sector partnerships, and digital infrastructure for education. The scans are intended to be comprehensive but are by no means exhaustive; nonetheless, we hope they will serve as a useful starting point for more in-depth discussions about opportunities and barriers in EdTech in specific countries, in this case, Pakistan. Although the scans mainly explore national-level EdTech policies, in this case, we also examine education sector plans and EdTech in two provinces - Punjab and Sindh, as they are home to 75\% of the country's population. Further, Pakistan's decentralised education system, introduced with the 18th Amendment ${ }^{1}$ is largely managed at the provincial level, with some guidance and direction from the federal government.

This report was originally written in June 2020. It is based primarily on desk research, with quality assurance provided by a country expert. Given how rapidly the educational technology landscape is evolving, the Hub plans to provide periodic updates. Table 1 provides a summary of the situation regarding EdTech in Pakistan.

Table 1. EdTech in Pakistan

\begin{tabular}{l|l} 
Policies & - National Information and Communication Technology \\
& Strategy for Education in Pakistan, 2004-05² \\
- & Digital Pakistan Policy $2018^{3}$ \\
- & Punjab IT Policy $2018^{4}$
\end{tabular}

\footnotetext{
See:

https://www.americanprogress.org/issues/security/news/2010/04/19/7587/the-18th-amendment -and-pakistans-political-transitions/

${ }^{2}$ Ministry of Education \& Education Sector Reform Assistance (ESRA) Program. (2010).

${ }^{3}$ Ministry of IT \& Telecom. (2018).

${ }^{4}$ Government of the Punjab. (2018).
} 


\begin{tabular}{|c|c|}
\hline Infrastructure & $\begin{array}{l}\text { - } 62 \% \text { of primary schools have electricity, compared to } 79 \% \text { of } \\
\text { middle schools, } 91 \% \text { of high schools and } 97 \% \text { of higher } \\
\text { secondary schools. } \\
\text { - } 91 \% \text { of households (PSLM } 2018-2019)^{6} \text { have grid electricity } \\
\text { while } 34 \% \text { have solar electricity (ASER, 2019). } \\
\text { - } 34 \% \text { of households have internet connectivity (PSLM } \\
\text { 2018-2019). } \\
\text { - } 95 \% \text { of households own a mobile phone (PSLM 2018-2019). } \\
\text { - At the national level, household ownership of computers } \\
\text { (14\%) (PSLM 2018-2019) }{ }^{8} \text { and radios (6\%) is low (Pakistan } \\
\text { DHS 2017-2018). }{ }^{10}\end{array}$ \\
\hline $\begin{array}{l}\text { Partners and } \\
\text { initiatives }\end{array}$ & $\begin{array}{l}\text { - The Ministry of Information Technology and } \\
\text { Telecommunication is responsible for creating an enabling } \\
\text { environment for the use of educational technology }{ }^{11} \text {. } \\
\text { - The Punjab Information Technology Board has a key role in } \\
\text { EdTech in Punjab province }{ }^{12} \text {. } \\
\text { - Similarly, in Sindh province, the Information Science and } \\
\text { Technology Department plays a key role in EdTech }{ }^{13} \text {. } \\
\text { - USAID, DFID, World Bank and GIZ have played a key role in } \\
\text { supporting EdTech initiatives in Pakistan. }\end{array}$ \\
\hline
\end{tabular}

\footnotetext{
${ }^{5}$ Government of Pakistan, Ministry of Federal Education and Professional Training, National Education Management Information System, \& Academy of Educational Planning and Management. (2018).

${ }^{6}$ Government of Pakistan. Pakistan Bureau of Statistics, Government of Pakistan, \& Ministry of Planning Development \& Special Initiatives. (2020).

${ }^{7}$ Government of Pakistan. Pakistan Bureau of Statistics, Government of Pakistan, \& Ministry of Planning Development \& Special Initiatives. (2020).

${ }^{8}$ Government of Pakistan. Pakistan Bureau of Statistics, Government of Pakistan, \& Ministry of Planning Development \& Special Initiatives. (2020).

${ }^{9}$ Government of Pakistan. Pakistan Bureau of Statistics, Government of Pakistan, \& Ministry of Planning Development \& Special Initiatives. (2020).

${ }^{10}$ National Institute of Population Studies. (2019).

${ }^{11}$ See: http://library.aepam.edu.pk/Books/Pakistan\%20Education\%20Statistics\%202016-17.pdf

12 See: https://www.pitb.gov.pk/

${ }^{13}$ See: https://istd.sindh.gov.pk/about
} 


\section{Covid-19}

\section{Country overview}

Pakistan has a federal government system consisting of seven federating units - four provinces, two autonomous regions and one capital territory.

For the last four decades, the country has witnessed several natural and human-made calamities, including massive floods, hurricanes, a powerful earthquake that caused nearly 100,000 deaths, political instability and terrorism and extreme violence associated with the 'war on terror'. All of this has severely affected Pakistan's economy, but it has also had a devastating impact on social, political and educational institutions. According to the World Economic Forum Global Competitiveness Report 2019 (Schwab, 2019), Pakistan is ranked 110 out of the 141 in the Global Competitiveness Index (GCI) while UNDP's Human Development Report 2019 (Conceição, P., \& UNDP, 2019), ranks Pakistan 152 out of 189 countries.

\footnotetext{
${ }^{14}$ Ministry of Federal Education and Professional Training. (2020).
} 


\section{Education system overview}

Article 25-A of the constitution (right to education) states: "The State shall provide free and compulsory education to all children of the age of five to sixteen years in such manner as may be determined by law." The Constitution further states that "The State shall remove illiteracy and provide free and compulsory secondary education within [the] minimum possible period" (Article 37-B) ${ }^{15}$.

The 18th constitutional amendment passed by the parliament of Pakistan in 2010, made education a provincial issue. The provinces of Sindh and Punjab have translated this legal responsibility into the Free and Compulsory Education Act, passed in 2013 and 2014, respectively.

In terms of curricula and syllabuses, Pakistan has three main education systems that function in parallel. There are public and private schools implementing the national curricula, private schools that follow the Cambridge Examination system, and Deeni Madrassas (religious seminaries) that teach the curriculum mainly produced by Wifaq-Ul-Madaris, the largest federation of Islamic Seminaries in Pakistan.

The education system has four levels that are defined at the national level and implemented at the provincial level (Table 2).

Table 2. Structure of the public sector education system ${ }^{16}$

\begin{tabular}{|l|l|l|l|}
\hline School level & Age group & Certificate types & $\begin{array}{l}\text { Certificate issuing } \\
\text { authorities }\end{array}$ \\
\hline Primary $([1] \mathrm{K}-5)$ & $5-10$ & $\begin{array}{l}\text { Primary school } \\
\text { certificate }\end{array}$ & $\begin{array}{l}\text { School / District } \\
\text { Education } \\
\text { Department }\end{array}$ \\
\hline Middle & $11-13$ & $\begin{array}{l}\text { Middle School } \\
\text { Certificate }\end{array}$ & $\begin{array}{l}\text { School / District } \\
\text { Education } \\
\text { Department }\end{array}$ \\
\hline Secondary & $14-15$ & $\begin{array}{l}\text { Matric / Secondary } \\
\text { School Certificate }\end{array}$ & $\begin{array}{l}\text { Board of } \\
\text { Intermediate and } \\
\text { Secondary } \\
\text { Education }\end{array}$ \\
\hline
\end{tabular}

\footnotetext{
${ }^{15}$ See: https://rtepakistan.org/about-rte-pakistan/

${ }^{16} \mathrm{~K}$ is generally referred as Katchi which is a pre-primary grade, aimed at readiness for schooling. So, it is not counted for primary schooling years.
} 


\begin{tabular}{|l|l|l|l|}
\hline Higher Secondary & $16-17$ & $\begin{array}{l}\text { Intermediate / } \\
\text { Higher Secondary } \\
\text { School Certificate }\end{array}$ & $\begin{array}{l}\text { Board of } \\
\text { Intermediate and } \\
\text { Secondary } \\
\text { Education }\end{array}$ \\
\hline
\end{tabular}

Pakistan is a signatory to several international treaties and instruments concerning free and compulsory education for all citizens. For example, the Universal Declaration of Human Rights (1948), United Nations Convention on the Rights of the Child (1989) ratified in 1990 , the Dakar Framework of Action (2000), and UN Sustainable Development Goals.

\subsection{Education sector progress and challenges}

Pakistan has made serious efforts to improve access to and the quality of education with reforms happening at a pace that has been described as "frenetic"17. The Pakistan economic survey (Government of Pakistan. Economic Adviser's Wing, Finance Division, 2019) and the PLMS-HIES (National Institute of Population Studies, 2019) report an increase in enrollment, the number of teachers and schools. However, in light of the magnitude of challenges that Pakistan's education sector faces, progress has been marginal. Learning poverty in Pakistan or the inability to read and understand a short age-appropriate text by the age of ten is 16.3 percentage points worse than the average for the South Asia region and 19.5 percentage points worse than the average for lower-middle-income countries (World Bank, 2019). Insufficient funding, inadequate or non-existent infrastructure, ill-equipped teachers, and poor governance have slowed the country's progress and reform efforts. Table 3 highlights key education statistics that give an overview of the sector.

According to the 2017 I-SAPS report cited in the Asian Development Bank Education Sector Assessment Report (2019), budget allocations for education in Punjab and Sindh in 2016-17 had limited financial space for education departments to invest in capacity-building and systems-strengthening activities. The report describes the composition of the budget allocation for primary education in Punjab as $96 \%$ salary, $2 \%$ non-salary and $2 \%$ development. At the secondary education level, $54 \%$ of the allocated budget is for salaries, 34\% for development and $12 \%$ for non-salary expenditures. In Sindh, the composition of the budget allocation for primary and secondary education was 93\% salary and 7\% non-salary. Historically, development partners have had a significant role in supporting Pakistan's education portfolio (Asian Development Bank, 2019). Large donors such as DFID, the EU, GIZ and the World Bank provide general or

\footnotetext{
17 See:
}

https://www.economist.com/briefing/2018/01/04/pakistan-is-home-to-the-most-frenetic-educati on-reforms-in-the-world 


\section{\#EdTechHub}

sector budget support while smaller donors provide support to local and international NGOs.

The Asian Development Bank sector assessment report recommends targeted investments and programmes to improve completion rates and learning levels in both provinces. In addition to ensuring appropriate funding levels, it is equally important that education budgets are better spent (Naviwala, 2016)..

Table $3 .^{18}$ Education statistics: key indicators (national data)

\begin{tabular}{|l|l|}
\hline GDP on education & $2.2 \%$ \\
\hline Population - children aged 5-16 & $51,530,105$ \\
\hline Number of children enrolled (urban) & $14,975,711$ \\
\hline Number of children enrolled (rural) & $25,709,408$ \\
\hline Total number enrolled (urban and rural) & $40,685,119$ \\
\hline Total number enrolled (Gross) & $34,205,220$ \\
\hline Total number enrolled (Net) & $28,685,802$ \\
\hline aNER (adjusted net enrolment rate) & $56 \%$ \\
\hline $\begin{array}{l}\text { Total number of out-of school children } \\
\text { (aged 5-16) }\end{array}$ & $22,844,303$ \\
\hline Out-of-school children (boys) & $\begin{array}{l}\text { At grade five, 59\% of children can read a } \\
\text { simple story in Urdu and 50\% in English }\end{array}$ \\
\hline Out-of-school children (girls) & $10,683,206$ \\
\hline Children who have never attended school & $12,161,097$ \\
\hline Children who have dropped out & $5,330,337$ \\
\hline Literacy score & \begin{tabular}{l}
17,966 \\
\hline Numeracy
\end{tabular} \\
\hline
\end{tabular}

${ }^{18}$ The statistics in this table come from the Pakistan Education Statistics 2016-17 by the Academy for Education Planning and Management and Annual Status of Education Report, ASER 2019; Pakistan Economic Survey 2018-19; Human Rights Watch 2018 


\begin{tabular}{|c|c|}
\hline Gender Disparity & $\begin{array}{l}32 \% \text { of primary-school-age girls are out of } \\
\text { school as compared to } 21 \% \text { of boys }\end{array}$ \\
\hline Pupil-teacher ratio & $\begin{array}{l}\text { primary } 32, \text { middle } 21 \text { and secondary and } \\
\text { higher secondary } 23\end{array}$ \\
\hline Pupil-classroom ratio & $\begin{array}{l}\text { primary } 38, \text { middle } 33 \text { and secondary and } \\
\text { higher secondary } 43\end{array}$ \\
\hline $\begin{array}{l}\text { Number of schools using multi-grade } \\
\text { teaching }\end{array}$ & $46 \%$ of primary schools and $18 \%$ schools \\
\hline $\begin{array}{l}\text { Ratio of primary schools to middle } \\
\text { schools }\end{array}$ & 3 \\
\hline Attendance in government schools & Teachers $87 \%$, Students $84 \%$ \\
\hline
\end{tabular}

\subsubsection{Data on children with disabilities}

According to the Annual Status of Education Report (ASER, 2019), at the national level, $22.2 \%$ of the surveyed government schools served children with disabilities compared to $16.6 \%$ of private schools. The number of children with disabilities in government schools as reported by the head teacher / school in-charge was 2,315, compared to 1,212 in private schools. These numbers are likely to be underreported given that household and school-level questionnaires in Pakistan do not probe beyond a yes / no question on disability and fail to capture different types of disabilities.

\subsection{Education Sector Plan}

The Education Sector Assessment Report 2019 developed by the Asian Development Bank (2019) found that Sindh and Punjab provinces largely use technology to monitor teacher attendance and student results for accountability purposes, and to communicate management decisions. Current sector plans in both provinces prioritise key actions for integrating the use of technology in education.

\subsubsection{Sindh Education Sector Plan and Roadmap}

Sindh's Education Sector Plan and Roadmap 2019-2024 (Government of Sindh. School Education \& Literacy Department.,2019) is a follow-on to the School Education Sector Plan 2014-2018 that targeted early childhood education as a reform priority but made slow progress in implementation (Asian Development Bank, 2019). The sector plan and roadmap sets out a long-term strategic vision for the government, focusing on: 


\section{\#EdTechHub}

- Ensuring inclusive and equitable access to quality education through various formal and non-formal educational modalities;

- Achieving effective learning outcomes through child-friendly and quality learning environments;

- Improving effective governance in the education sector through strong accountability systems, adequate resources and strong capacities at all levels, without political interference and with effective political will.

The strategic vision outlines three thematic goals and a set of priorities and objectives for each goal.

Table 4. Sindh province: education sector goals, priorities and objectives

\begin{tabular}{|c|c|c|}
\hline Goal & Priorities & Objectives \\
\hline Access & $\begin{array}{l}\text { Increase equitable enrollment } \\
\text { and ensure retention for children } \\
\text { and adolescents at all levels, } \\
\text { including provision of literacy for } \\
\text { youths. }\end{array}$ & $\begin{array}{l}\text { - Reach out-of-school } \\
\text { children and youth } \\
\text { - Equitable and adequate } \\
\text { provision of school } \\
\text { infrastructure } \\
\text { - Equitable enrollment and } \\
\text { retention }\end{array}$ \\
\hline Quality & $\begin{array}{l}\text { Improve capacity of quality } \\
\text { delivery systems at provincial } \\
\text { and district levels, including } \\
\text { meritorious teacher recruitment, } \\
\text { teacher training and professional } \\
\text { development; curriculum, } \\
\text { textbook and learning materials; } \\
\text { student learning outcomes and } \\
\text { quality assurance. }\end{array}$ & $\begin{array}{l}\text { - Merit-based recruitment, } \\
\text { qualification and } \\
\text { professional development } \\
\text { - Quality inputs and } \\
\text { processes }\end{array}$ \\
\hline Governance & $\begin{array}{l}\text { More effective and accountable } \\
\text { use of resources at all levels. }\end{array}$ & $\begin{array}{l}\text { - Professional educational } \\
\text { leadership and } \\
\text { management } \\
\text { - Improved resources } \\
\text { allocation and utilisation } \\
\text { - Effective strategic planning } \\
\text { and monitoring and } \\
\text { education }\end{array}$ \\
\hline
\end{tabular}




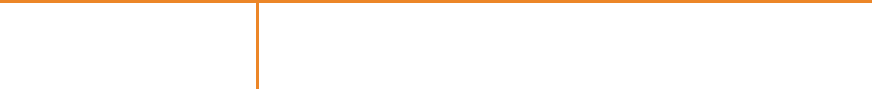

\subsubsection{EdTech priorities in Sindh's school education sector}

The Sindh School Education Sector Roadmap (2019-2024) outlines the following priorities for EdTech in the region:

- Digitise the teaching / learning resources and assessment practices in public schools;

- Enable students and teachers to use technology and improve learning outcomes;

- Establish an e-assessment system;

- Seek services of organisations developing EdTech to make the content child friendly and more engaging for all learners, especially those in rural areas.

\subsubsection{Punjab's Education Sector Plan}

The Punjab Education Sector Plan 2019 / 20-2023 / 2024 updates the Punjab Education Sector Plan 2013-2017 (Government of the Punjab, 2019). It identifies three overarching strategic areas for advancing education sector reforms in Punjab, including:

1. Quality and learning outcomes

2. Access and equity

3. Governance and management

The plan also identifies five priority programmes that align with these three areas:

1. Improve teacher and learning practices to achieve better learning outcomes.

2. Provide adequate and sufficient access to education for children from pre-primary to secondary, including marginalised children and those with special needs.

3. Promote quality education in a safe, inclusive environment for children.

4. Strengthen good governance of the education sector for equitable access and high-quality education.

5. Promote effective leadership and management of the education sector for better service delivery. 


\subsubsection{EdTech priorities in the Punjab school education sector plan}

The Punjab Education Sector Plan (Government of the Punjab, 2019) outlines the following priorities for EdTech in the regions:

- Introduce a strong focus on science, technology, engineering, arts and mathematics (STEAM) with a focus on secondary grade and technical vocational programmes;

- Leverage technology to improve teacher continuous development programmes. 


\section{EdTech policy and strategy}

In this section, we describe Pakistan's national ICT policy and include a brief look at the ICT in education policy.

\subsection{National Policy}

Pakistan formulated its first ever National Information \& Communication Technology (NICT) Strategy for Education through a consultative process in 2004-2005 (Ministry of Education \& Education Sector Reform Assistance (ESRA) Program, 2010). The NICT strategy acknowledges the potential for ICT in education to improve the quality and accessibility of education, strengthen teacher education and contribute to gains in learning. The strategy outlines the following actions for ministries, education departments and district education offices:

- Establish an online educational portal with appropriate content for students;

- Collect and adapt international open resources;

- Maximise opportunities for professional development through different ICT platforms such as interactive radio instruction (IRI), television, open distance learning and online resources that are context-specific and geographically appropriate;

- Adapt international ICT standards for education;

- Provide distance learning to a large number of individuals by establishing virtual classroom education programmes using online, internet and / or video facilities.

- Establish a national educational intranet (linked to the internet) to enable sharing of electronic libraries of teaching and research materials among educational institutions and faculty;

- Enhance ICT infrastructure of schools with a focus on schools above grade 8.

\subsection{ICT in Education Policy}

The National Education Policy (Ministry of Education, 2009) adopted by all federating units emphasises the use of ICT in education. The policy promotes the use of ICTs in line with the 2004-2005 NICT Strategy (Ministry of Education \& Education Sector Reform Assistance (ESRA) Program, 2010). It provides guidelines for integrating ICTs into education and strengthening non-formal education systems. The policy highlights that "ICTs shall be utilised creatively to assist teachers and students with a wide range of abilities and from varied socio-economic backgrounds." Given the decentralised nature of the education system, Pakistan requires a unique and differentiated approach to work with the provinces. 


\section{\#EdTechHub}

In 2018, the Federal Ministry of Education and Professional Training published the National Education Policy Framework, as guidance for the provinces and to re-emphasise the importance of using technology in education, specifically to:

- $\quad$ enhance teacher and student content knowledge;

- improve access to free education content;

- provide offline content solutions and options in remote areas;

- strengthen education management systems.

The Pakistan Economic Survey Report 2018-19 (Government of Pakistan. Economic Adviser's Wing, Finance Division, 2019) recognises the importance of digital solutions for the economic growth and transformation of under-served populations. The report describes how, with the advancement of technologies and the proliferation of digital platforms and enabling apps, user behaviour is shifting from voice- and data-centric services to app-centric services. Under Vision Pakistan 2025, the Ministry of Information and Technology has planned to increase broadband spectrum currently at 3\% to $30 \%$ by 2025 , across the country. Finally, the guiding framework for the recently introduced Single National Curriculum ${ }^{19}$ also mentions the use of ICT.

${ }^{19}$ See:

http://mofept.gov.pk/ProjectDetail/MzkyNDc2MjMtY2VjYy00ZDA4LTk5OTUtNzUyNDI3ZWMzN2R m\#: : :text=Single\%20National\%20Curriculum\%20(SNA)\&text=The\%20aim\%20of\%20Single\%20Na tional,receive $\% 20 a \% 20$ high\%20quality\%20Education. 


\section{ICT infrastructure}

The government of Pakistan recognises the economic benefits that ICT brings to all sectors and strives to build a strong digital ecosystem (Ministry of IT \& Telecom, 2018). The Telecom sector in Pakistan is deregulated and provides a level playing field for the telecom companies operating in Pakistan for increasing connectivity and quality of services across Pakistan. Likewise, the Universal Service Fund is increasingly expanding ICT infrastructure in hard-to-access geographical areas on a priority basis.

At the household level, ownership of TV is high in Pakistan (74\%), as is ownership of mobile phones (76\%) (Table 5). In contrast, only $6 \%$ of households own a radio. Similarly, ownership of computers (14\%) and access to the internet (25\%) are both low. According to the Pakistan Telecommunication Authority (PTA) (2019) and the Techjuice report (2020), 76\% of the population possess basic feature mobile phones and $56 \%$ of the population own smartphones. The ASER (2019) and PTA (2019) reports reveal that $91 \%$ of households use WhatsApp and 70\% use SMS. Access to WhatsApp is similar across urban and rural households (93\% and $90 \%)$, while access to SMS services is more prevalent among urban (80\%) than rural households (59\%).

Table $5 .^{20}$ Percentage of households with a television, radio, computer, mobile phone and smartphone and that have access to the internet at home and to SMS and WhatsApp ${ }^{21}$

\begin{tabular}{|l|r|r|r|}
\hline & Rural & Urban & National \\
\hline TV & 60 & 88 & 74 \\
\hline Radio & 7 & 5 & 6 \\
\hline Computer & 7 & 21 & 14 \\
\hline Internet connectivity & 15 & 36 & 25 \\
\hline Basic feature mobile phone & 66 & 85 & 76 \\
\hline Smartphone & 38 & 73 & 56 \\
\hline SMS service & 59 & 80 & 70 \\
\hline
\end{tabular}

\footnotetext{
${ }^{20}$ To accelerate digital transformation in Pakistan (2019) GSM Association, Pakistan Social and Living Standards Measurements (PSLM), 2018-19, https://www.pta.gov.pk/en/telecom-indicators; Annual Report 2019, Pakistan Telecommunication Authority; DHS, 2017-18 - Final Report; Potential benefits from sub-700 MHz spectrum in Pakistan: A report by GSMA 2015 https://www.techjuice.pk/mobile-phone-users-in-pakistan-crosses-161-million-mark/

${ }^{21}$ Given that authentic sources of national data on radio listeners are not available, data for urban and rural areas may not be reliable.
} 
The PSLM (2019) survey report discloses that individuals mostly commonly use computers / laptops / tablets for entertainment and to perform basic functions - 65\% use it for copying-moving, 56\% copying-pasting, 47\% for sending an e-mail, $19 \%$ for connecting-installing, 31\% for finding-downloading, 32\% for transferring files, 43\% for social media and $59 \%$ for entertainment. Only $26 \%$ of individuals use these tools for more advanced activities like working on spreadsheets, preparing powerpoint presentations (18\%) or programming (17\%).

Table 6. ${ }^{22}$ National Data on ICT Skills: Percentage of individuals with use of computer / laptop I tablet and by type of ICT Skill

\begin{tabular}{|l|r|}
\hline \multicolumn{1}{|c|}{ ICT Skill } & \multicolumn{2}{|c|}{ Percentage } \\
\hline Copy-move & 65 \\
\hline Copy-paste & 56 \\
\hline Send e-mail & 47 \\
\hline Spreadsheets & 26 \\
\hline Connecting-installing & 19 \\
\hline Finding-downloading & 31 \\
\hline Electronic presentation & 18 \\
\hline Transferring files & 32 \\
\hline Programming & 17 \\
\hline Social Media & 43 \\
\hline Entertainment & 59 \\
\hline
\end{tabular}

22 Pakistan Social and Living Standards Measurements (PSLM), 2018-19 


\section{Key partners and initiatives in EdTech}

This section looks at the work and roles and responsibilities of key partners with regard to EdTech in Pakistan, including government and non-governmental agencies, as well as EdTech initiatives.

\subsection{Government agencies}

Table 7. Government partners in EdTech

\begin{tabular}{|c|c|}
\hline Ministry / Agency & Roles and responsibilities in EdTech \\
\hline $\begin{array}{l}\text { Federal Ministry of Education } \\
\text { and Professional Training }\end{array}$ & $\begin{array}{l}\text { - Ensure national cohesion on education } \\
\text { policies and reforms, including ICT } \\
\text { - Foster international cooperation and } \\
\text { coordination on education matters } \\
\text { - Collect, analyse and disseminate } \\
\text { information on key education indicators }\end{array}$ \\
\hline $\begin{array}{l}\text { Ministry of Information } \\
\text { Technology and } \\
\text { Telecommunication }^{24}\end{array}$ & $\begin{array}{l}\text { - Formulate the national policy for the } \\
\text { development and improvement of } \\
\text { Information Technology and } \\
\text { Telecommunications, including related } \\
\text { infrastructure } \\
\text { - Promote information technology } \\
\text { applications } \\
\text { - Develop guidelines for the standardisation } \\
\text { of software for use within the government }\end{array}$ \\
\hline \multicolumn{2}{|l|}{ In the province of Punjab } \\
\hline $\begin{array}{l}\text { School Education } \\
\text { Department-Government of } \\
\text { Punjab }\end{array}$ & $\begin{array}{l}\text { - Legislation, policy formulation and } \\
\text { planning for school education; including } \\
\text { ICT } \\
\text { - Formulation of curricula, syllabuses, } \\
\text { production and publication of textbooks } \\
\text { and teaching and learning materials (print } \\
\text { and digital) for grades } \mathrm{K}-12\end{array}$ \\
\hline
\end{tabular}

23 See:

http://mofept.gov.pk/ProjectDetail/MzkyNDc2MjMtY2VjYy00ZDA4LTk50TUtNzUyNDI3ZWMzN2R $\underline{\mathrm{m}}$

${ }^{24}$ See: https://moitt.gov.pk/

25 See: https://schools.punjab.gov.pk/ 


\begin{tabular}{|c|c|}
\hline & $\begin{array}{l}\text { - Monitoring, assessment, examination and } \\
\text { - } \text { Devaluation of school systems } \\
\text { (pre-service and in-service teacher } \\
\text { education programme) } \\
\text { - Planning, provision, management and } \\
\text { monitoring of school infrastructure and } \\
\text { grants to students } \\
\text { The Programme Monitoring and } \\
\text { Implementation Unit supervises and } \\
\text { manages monthly school monitoring } \\
\text { activities and the annual school census; } \\
\text { data are collected by monitoring and } \\
\text { evaluation assistants who digitally submit } \\
\text { forms as they are conducting spot visits to } \\
\text { schools, giving it access to real-time data }\end{array}$ \\
\hline $\begin{array}{l}\text { Punjab Information } \\
\text { Technology Board }^{26}\end{array}$ & $\begin{array}{l}\text { - Maintaining the foundational information } \\
\text { Technology (IT) infrastructure and system } \\
\text { of Punjab } \\
\text { - Provide IT system solutions and } \\
\text { standardisation for all departments of the } \\
\text { government of Punjab }\end{array}$ \\
\hline \multicolumn{2}{|l|}{ In the province of Sindh } \\
\hline $\begin{array}{l}\text { Sindh Education and Literacy } \\
\text { Department }^{27}\end{array}$ & $\begin{array}{l}\text { - Legislation, policy formulation and } \\
\text { planning for school education; including } \\
\text { ICT } \\
\text { - Formulation of curricula, syllabuses, } \\
\text { production and publication of textbooks } \\
\text { and teaching and learning materials (print } \\
\text { and digital) for grades K-12 } \\
\text { - Monitoring, assessment, examination and } \\
\text { evaluation of school systems; the Sindh } \\
\text { School Monitoring System collects, } \\
\text { analyses and disseminates real-time data } \\
\text { on key school-level indicators }\end{array}$ \\
\hline
\end{tabular}

${ }^{26}$ See: https://www.pitb.gov.pk/

${ }^{27}$ See: http://www.sindheducation.gov.pk/ 


\begin{tabular}{|c|c|}
\hline & $\begin{array}{l}\text { Development of education workforce } \\
\text { (pre-service and in-service teacher } \\
\text { education programme) } \\
\text { - Planning, provision, management and } \\
\text { monitoring of school infrastructure and } \\
\text { grants to students }\end{array}$ \\
\hline $\begin{array}{l}\text { Sindh Education Foundation } \\
(\mathrm{SEF})^{28}\end{array}$ & $\begin{array}{l}\text { - A semi-government organisation } \\
\text { established in } 1992 \text { that has been } \\
\text { supporting the use of educational } \\
\text { technology in teaching and learning, } \\
\text { including, through the provision of tablets } \\
\text { for students and training, to help teachers } \\
\text { supplement their teaching with ICTs in } \\
\text { Sindh province }\end{array}$ \\
\hline $\begin{array}{l}\text { Information Science and } \\
\text { Technology Department }{ }^{29}\end{array}$ & $\begin{array}{l}\text { - Maintain the foundational IT infrastructure } \\
\text { and system } \\
\text { - Provide IT system solutions and } \\
\text { standardisation for all government } \\
\text { departments. }\end{array}$ \\
\hline
\end{tabular}

\subsection{Non-governmental agencies}

USAID, DFID, World Bank, Asian Development Bank, Islamic Development Bank, GIZ, JICA, CIDA and the European Commission have a long history of supporting the education system in Pakistan. The China International Development Cooperation Agency and the Bill and Melinda Gates Foundation are recent additions to the list. UN Agencies have also been long-term official partners with the government of Pakistan. Of these partners, USAID, DFID, World Bank and GIZ have played a key role in supporting EdTech initiatives. DFID funding supports initiatives that includes IIm IDEA2, ${ }^{30}$ which awards grants to local, social EdTech entrepreneurs for developing customised EdTech products / solutions for the education sector in Pakistan. One of the entrepreneurs, SABAQ / MUSE ${ }^{31}$, described in greater detail in Table 7, has partnered with the federal and provincial ministries of education to provide distance-learning solutions to children and families during school closures in response to Covid-19.

\footnotetext{
${ }^{28}$ See: https://www.sef.org.pk/introducing-smart-teaching-and-learninginstal/

${ }^{29}$ See: https://istd.sindh.gov.pk/about

${ }^{30}$ See: https://www.camb-ed.com/article/241/ilm-ideas-2

${ }^{31}$ See: https://sabaq.edu.pk/
} 


\section{\#EdTechHub}

In 2015, the government introduced an INGO Policy ${ }^{32}$ that outlines the rules and regulations for international NGOs working in Pakistan, including a requirement to sign an MOU in advance of any operations. This restriction has limited the participation of INGOs working in the education sector ${ }^{33}$.

National NGOs supporting EdTech initiatives in Pakistan include, the Aga Khan Foundation, Pakistan, The Citizens Foundation,_READ Foundation, Idara-e-Taleem-o-Aagahi, Sabaq and_Development in Literacy ${ }^{34}$.

Further, the National Incubation Center ${ }^{35}$, a public-private partnership between the Ministry of Information Technology and Telecommunication, Ignite - National Technology Fund, Jazz and Teamup plays a catalytic role in facilitating innovative EdTech startups. The Jazz Foundation's Make Your Mark Programme has launched the Jazz Smart School Programme ${ }^{36}$ in collaboration with Knowledge Platform, a blended-learning solution that uses technology to help teachers fill gaps in knowledge, this is described in greater detail in Table 8. Other organisations that are broadly supporting entrepreneurship in technology include Invest 2 Innovate ${ }^{37}$ and the Social Innovation Lab at LUMS ${ }^{38}$. Lastly and notably, the IIm Association ${ }^{39}$ is a newly formed association that has been established to represent the education innovation industry in Pakistan.

\subsection{EdTech initiatives}

Although we have focused our scoping activities on initiatives in primary and secondary education, it is worth highlighting Pakistan's two technology-based higher education institutions. The first is the Virtual University, ${ }^{40}$ a public-sector, not-for-profit institution that has been using TV broadcasts and the internet to deliver courses to students across Pakistan since 2002. The other, Allama Iqbal Open University ${ }^{41}$ opened its doors in 1974 with the aim of providing education opportunities for students who cannot leave their homes and jobs, including women and learners in remote areas of the country.

\footnotetext{
${ }^{32}$ See: https://ingo.interior.gov.pk/

${ }^{33}$ See: https://www.devex.com/news/pakistan-uses-regulations-to-tighten-grip-on-ingos-91003

${ }^{34}$ See: https://www.akdn.org/where-we-work/south-asia/pakistan; https://www.tcf.org.pk/; http://www.readfoundation.org/; http://itacec.org/; https://sabaq.pk/; https://www.dil.org/

${ }^{35}$ See: http://nicpakistan.pk/

${ }^{36}$ See: http://www.jazzfoundation.com.pk/our-program/education/

${ }^{37}$ See: http://invest2innovate.com/incubate/

${ }^{38}$ See: https://talloiresnetwork.tufts.edu/lahore-university-of-management-sciences-pakistan-2/

${ }^{39}$ See: http://www.ilmassociation.com/

${ }^{40}$ See: http://www.vu.edu.pk/AboutUs/AboutVU.aspx

${ }^{41}$ See: $\underline{\text { https://www.aiou.edu.pk/ }}$
} 


\section{\#EdTechHub}

Table 8 presents information about selected local EdTech initiatives in Pakistan. The descriptions of the initiatives are based on information available on the internet. We used the following criteria to determine which initiatives to include or exclude:

1. The initiative is developing and promoting teaching and learning using EdTech for learners in the 5-16 age group.

2. The initiative has national reach or is implemented in the provinces of Sindh or Punjab.

3. Preference is given to initiatives that are owned by the government or have developed a partnership with the government.

Table 8. Key EdTech initiatives in Pakistan

\begin{tabular}{|c|c|}
\hline Initiative & Details \\
\hline Aahung Pakistan ${ }^{42}$ & $\begin{array}{l}\text { Overview: A Karachi-based NGO with national outreach. } \\
\text { Since 2010, it has aimed to improve the sexual and } \\
\text { reproductive health and rights (SRHR) of men, women } \\
\text { and adolescent girls across Pakistan. Aahung Pakistan } \\
\text { has a long history of successfully implementing } \\
\text { life-skills-based education for young girls in Pakistan } \\
\text { especially in slums and the remotest areas. } \\
\text { Target Group: Adolescent girls (for life-skills-based } \\
\text { education). } \\
\text { Technology: AR (augmented reality) Videos / audios } \\
\text { hosted on their official website for online access. } \\
\text { Reach / Scale: Punjab, Sindh and nationally } \\
\text { Implementing organisation: Aahung Pakistan } \\
\text { Government Partner: Ministry of Human Rights, Health } \\
\text { and Provincial Women's Development Departments, } \\
\text { Population Welfare, Health and Education } \\
\text { Status of Implementation: } 2010 \text { - }\end{array}$ \\
\hline
\end{tabular}

${ }^{42}$ See: https://www.aahung.org/resources 


\begin{tabular}{|c|c|}
\hline $\begin{array}{l}\text { Bolo_Read Along App } \\
\text { by Google })^{43}\end{array}$ & $\begin{array}{l}\text { On May 8, 2020, Google Pakistan launched a local } \\
\text { version of Read Along Bolo (bolo means speak) as an } \\
\text { educational response to Covid- } 19 \text {. }\end{array}$ \\
\hline KarMuqabla ${ }^{44}$ & $\begin{array}{l}\text { Overview: KarMuqabla is a product of Houndbyte } \\
\text { Technologies accessible through the website. } \\
\text { Target Group: Grades 5-10 } \\
\text { Technology: digitisation of textbooks (interactive pdfs), } \\
\text { gamification of the content (children play educational } \\
\text { games). } \\
\text { Reach / Scale: n/a } \\
\text { Implementing organisation: Houndbyte Technologies } \\
\text { Government Partner: n/a } \\
\text { Status of Implementation: Ongoing }\end{array}$ \\
\hline Knowledge Platform ${ }^{45}$ & $\begin{array}{l}\text { Overview: Knowledge Platform is a Singapore-based, } \\
\text { global company founded in 2000, focusing on a number } \\
\text { of countries in Asia including Pakistan. In Pakistan, } \\
\text { Knowledge Platform is implementing two initiatives: } \\
\text { Learn Smart Pakistan (a free, cloud platform for } \\
\text { students) and Learn Smart Classroom (in-school, } \\
\text { blended-learning system platform). } \\
\text { Target Group: K-12, teachers and educational } \\
\text { institutions / systems. } \\
\text { Technology: In-school blended-learning solution. } \\
\text { Laptops are pre-loaded with digital lessons containing } \\
\text { videos, class activities and assessments. Teachers are } \\
\text { empowered to blend these digital lessons with their } \\
\text { traditional teaching. } \\
\text { Mobile data is transferred to a cloud based learning } \\
\text { management system (LMS), data / files can be retrieved } \\
\text { by teachers and students at home. }\end{array}$ \\
\hline
\end{tabular}

${ }^{43}$ See: https://play.google.com/store/apps/details?id=com.google.android.apps.seekh\&hl=en

${ }^{44}$ See: https://www.karmuqabla.com/

${ }^{45}$ See: https://www.knowledgeplatform.com/ 


\begin{tabular}{|c|c|}
\hline & $\begin{array}{l}\text { Reach / Scale: The app is available on Google Play and } \\
\text { used in government schools in Islamabad Capital } \\
\text { Territory and private schools in other parts of Pakistan. } \\
\text { Implementing organisation: Knowledge Platform } \\
\text { Government Partner: Federal directorate of education, } \\
\text { Islamabad, School Education Department, Punjab, } \\
\text { Federal Ministry of Education } \\
\text { Status of Implementation: Ongoing }\end{array}$ \\
\hline SABAQ Foundation ${ }^{46}$ & $\begin{array}{l}\text { Overview: Sabaq Foundation Trust commonly known as } \\
\text { Sabaq Foundation or 'Sabaq' founded in } 2012 . \\
\text { Target Group: Grades 6-12 } \\
\text { Technology: Pre-built Sabaq Lite consists of a Raspberry } \\
\text { Pi computer with 128GB SD Card, a Wi-Fi Router, Clickers } \\
\text { and Uninterruptible Power Supply (UPS) with 6-8 hours } \\
\text { of battery backup. Sabaq Lite is being provided to } \\
\text { schools as an offline solution, and the videos and } \\
\text { practice tests do not require an internet connection. } \\
\text { Online materials are also accessible on their website. } \\
\text { Reach / Scale: National } \\
\text { Implementing organisation: Sabaq Foundation } \\
\text { Government Partner: Federal Ministry of Education } \\
\text { Status of Implementation: Ongoing }\end{array}$ \\
\hline SABAQ\&MUSE ${ }^{47}$ & $\begin{array}{l}\text { Overview: SABAQ is an EdTech organisation promoting } \\
\text { the use of technology in education and is a subsidiary of } \\
\text { Multinet Pakistan, a leading provider of information and } \\
\text { communication solutions. } \\
\text { Target Group: Primary grades. The content covers Urdu, } \\
\text { maths, science and Sindhi } \\
\text { Technology: SABAQ Tab, a 7" Android tablet containing } \\
\text { Kindergarten to Grade } 5 \text { content; the SMART Kit, a device } \\
\text { to convert any LED and projector display into a SABAQ }\end{array}$ \\
\hline
\end{tabular}

${ }^{46}$ See: https://sabaq.pk/

${ }^{47}$ See: https://sabaq.edu.pk/ 


\begin{tabular}{|c|c|}
\hline & $\begin{array}{l}\text { teaching resource; gamified apps and the SMART } \\
\text { monitoring and evaluation portal. Muse is an e-learning } \\
\text { app developed by SABAQ that is available on Google Play } \\
\text { Reach / Scale: SABAQ's digital content is being used in } \\
\text { government and foundation schools across Pakistan as } \\
\text { well as in Citizens Foundations schools, one of the } \\
\text { country's largest education not-for-profit organisations. } \\
\text { To ensure learners can access its content, SABAQ has } \\
\text { established 509 SABAQ Centers in three districts of the } \\
\text { province of Sindh with an outreach of } 21,369 \text { children } \\
\text { (Siddique, 2018). } \\
\text { Implementing organisation: SABAQ Foundation } \\
\text { Government Partner: Federal Ministry of Education, } \\
\text { Government of Sindh, State of Azad Jammu and Kashmir, } \\
\text { and Gilgit-Baltistan } \\
\text { Status of Implementation: Ongoing }\end{array}$ \\
\hline Taleemabad $^{48}$ & $\begin{array}{l}\text { Overview: Taleemabad platform is a project of _ Orenda } \\
\text { Private Limited, a local social entrepreneurial initiative } \\
\text { launched in } 2017 . \text { The platform initially produced Khan } \\
\text { Academy-like videos for young children, but after } \\
\text { learning from experience switched to developing } \\
\text { animated cartoon series called 'Taleemabad'. } \\
\text { Taleemabad receives support from the Malala Fund. } \\
\text { Target Group: Primary and middle grades } \\
\text { Technology: Digital content is produced with VR (virtual } \\
\text { reality), AVR (augmented virtual reality) and animations. } \\
\text { In addition to an Android app Taleemabad uses closed } \\
\text { data loops, has offline availability and is integrated with } \\
\text { Google firebase products. } \\
\text { Reach / Scale: National, with 179,000 beneficiaries } \\
\text { reached } \\
\text { Implementing organisation: Orenda Private Limited } \\
\text { Government Partner: n/a }\end{array}$ \\
\hline
\end{tabular}

${ }^{48}$ See: http://www.orendaproject.org/ 


\begin{tabular}{|c|c|}
\hline & Status of Implementation: Ongoing \\
\hline TeleTaleem ${ }^{49}$ & $\begin{array}{l}\text { Overview: TeleTaleem (T2), a social enterprise, has been } \\
\text { leveraging ICT to connect users with quality learning } \\
\text { opportunities across all boundaries since } 2010 . \\
\text { Target Group: Pre-primary up to higher secondary } \\
\text { grades, teachers, school and district educational } \\
\text { leadership. } \\
\text { Technology: } \\
\text { - T2 Mobile Van (with satellite based internet } \\
\quad \text { connectivity, an Uninterruptible Power Supply and } \\
\text { - } \text { tablets that children can use and return) } \\
\text { - design, assignments and lesson plans) } \\
\text { - Content Management: (training videos, animated } \\
\text { content, activity projects and e-textbooks) } \\
\text { • Live Virtual Class: (ICT-assisted instruction, tools, } \\
\text { - audio / video interactivity and whiteboard) } \\
\text { - Collaboration: (groups, forums, discussion board, } \\
\text { chat) }\end{array}$ \\
\hline TEXT Private Ltd & $\begin{array}{l}\text { Overview: Established in 2013, TEXT offers a low-cost, } \\
\text { mobile-phone-based integrated learning and }\end{array}$ \\
\hline
\end{tabular}

${ }^{49}$ See: https://www.teletaleem.com/ 


\begin{tabular}{|c|c|}
\hline & $\begin{array}{l}\text { accountability system for teachers, parents and } \\
\text { management. } \\
\text { Target Group: Teachers, parents and management. } \\
\text { Technology: Basic mobile phone with GSM enabled SIM. } \\
\text { TEXT also runs data analytics to provide customised } \\
\text { support and information to clients. } \\
\text { Reach / Scale: TEXT implemented the ILMI and Sitarey } \\
\text { model in government schools in Sindh (a cloud-based } \\
\text { SMS service which connects teachers, parents, } \\
\text { school-leaders and students to the Department of } \\
\text { Education). The Sindh government also benefited from } \\
\text { the TEXT platform by using it to monitor the fidelity of } \\
\text { teacher attendance and system accountability. TEXT } \\
\text { intends to expand the model in Balochistan province and } \\
\text { Azad Jammu and Kashmir. } \\
\text { Implementing organisation: TEXT Private Limited } \\
\text { Government Partner: TEXT has partnered with various } \\
\text { public-sector institutions which also include the } \\
\text { Education and Health Department, Government of } \\
\text { Sindh. } \\
\text { Status of Implementation: Ongoing }\end{array}$ \\
\hline toffeetv $^{50}$ & $\begin{array}{l}\text { Overview: toffee tv first went online in 2011. toffee TV is } \\
\text { focused on promoting Urdu by producing videos of Urdu } \\
\text { songs from storybooks that are / were popular among } \\
\text { kids of a relatively older generation. } \\
\text { Target Group: Primary and middle-grade children } \\
\text { Technology: Animated videos. Videos are mainly hosted } \\
\text { on their YouTube channel. } \\
\text { Reach / Scale: Information not available } \\
\text { Implementing organisation: toffeetv } \\
\text { Government Partner: Federal Ministry of Education and } \\
\text { Professional Training }\end{array}$ \\
\hline
\end{tabular}

${ }^{50}$ See: https://toffeetv.com/about/ 


\begin{tabular}{|c|c|}
\hline & Status of Implementation: Ongoing \\
\hline $\begin{array}{l}\text { USAID funded Pakistan } \\
\text { Reading Project (PRP) }\end{array}$ & $\begin{array}{l}\text { Overview: The USAID-funded Pakistan Reading Project } \\
\text { (PRP) initiated in 2013, developed early-grade reading } \\
\text { learning materials in Urdu, Sindhi, Pashto, Balochi and } \\
\text { Brahui in collaboration with federal and provincial } \\
\text { education departments. } \\
\text { Target Group: Grades } 1 \text { and } 2 \text { (PRP followed a research } \\
\text { based approach for developing the reading learning } \\
\text { material - a detailed framework for teaching reading) } \\
\text { Technology: PRP has digitised most of its material in PDF } \\
\text { format. They also have teaching and learning materials } \\
\text { available in audio and video format. PRP rendered their } \\
\text { digital content on tablets distributed by the project to the } \\
\text { partner schools. } \\
\text { Reach/Scale: } 2,000,000+ \\
\text { Implementing organisation: International Rescue } \\
\text { Committee } \\
\text { Government Partner: Federal and all federating units } \\
\text { (except for the Government of Punjab) } \\
\text { Status of Implementation: Ongoing }\end{array}$ \\
\hline Wondertree ${ }^{52}$ & $\begin{array}{l}\text { Overview: Wondertree is a local EdTech start-up } \\
\text { founded in 2015. It's mission is to design, develop and } \\
\text { provide affordable education and therapeutic solutions } \\
\text { to parents, children, families and teachers for children / } \\
\text { persons with special educational needs and disabilities } \\
\text { (SEND), especially those living in the under-served and } \\
\text { rural areas of Pakistan. } \\
\text { Target Group: children with SEND, parents and teachers } \\
\text { Technology: augmented reality games for therapy and } \\
\text { education. } \\
\text { Implementing organisation: Wondertree.co }\end{array}$ \\
\hline
\end{tabular}

${ }^{51}$ See: http://www.pakreading.org.pk/resources/publications/reading-learning-material

${ }^{52}$ See: https://wondertree.co/about/ 


\begin{tabular}{|c|c|}
\hline & $\begin{array}{l}\text { Government Partner: n/a } \\
\text { Status of Implementation: Ongoing }\end{array}$ \\
\hline $\begin{array}{l}\text { Family Education } \\
\text { Services } \\
\text { Foundation(FESF) } \\
\text { Technology-Based } \\
\text { Deaf Education } \\
\text { Programme (TBDE) }\end{array}$ & $\begin{array}{l}\text { Overview: A project that aims to improve the quality of } \\
\text { education for deaf children in Pakistan. The project } \\
\text { provides schools and communities across the country } \\
\text { who work with deaf children with a full repository of } \\
\text { digital learning resources in Pakistan Sign Language } \\
\text { (PSL), free of cost. } \\
\text { Target Group: Deaf children from K-12. } \\
\text { Technology: Online portal with learning tutorials, life } \\
\text { skills, stories and literacy programmes. } \\
\text { Implementing organisation: Family Education Services } \\
\text { Foundation } \\
\text { Government Partner: The programme has been } \\
\text { pilot-tested in numerous locations and integrated into } \\
\text { FESF's five Deaf Reach Schools in the province of Sindh. } \\
\text { Status of Implementation: Ongoing }\end{array}$ \\
\hline
\end{tabular}

\section{Pakistan's national education response and resillience plan for Covid-19}

Pakistan was the fifth country in the world, to close schools during the last week of February 2020. The government's priority was to ensure the wellbeing of teachers, students and families. The closure of educational institutions impacted more than 50 million learners from pre-primary up to university level. Federal, provincial and regional governments have been working hard to design and implement innovative strategies and solutions to ensure learning continues during school closures.

The Federal Ministry of Education and Professional Training with assistance from the Federal Ministry of Information and Broadcasting, and in partnership with private sector partners including the Sabaq Foundation and Taleemabad, responded to this challenge in a timely manner by launching distance learning initiatives such as Teleschoo ${ }^{54}$.

\footnotetext{
${ }^{53}$ See:

https://www.fesf.org.pk/technology-based-deaf-education-initiative-by-fesf-pakistan-wins-prestig ious-wise-awards/

${ }^{54}$ See:

http://mofept.gov.pk/Sitelmage/Misc/images/Teleschool\%20Inuguration\%2013-04-2020.jpg
} 
Teleschool broadcasts teaching and learning content for different subjects for grades $\mathrm{K}-12$ from 8 am to $6 \mathrm{pm}$ daily. The provincial governments have also adopted innovative approaches to reach students and their families. The Punjab School Education Department launched TaleemGhar, ${ }^{55}$ a cable TV programme, and an online digital app called e-learn Punjab. ${ }^{56}$ The Taleem Ghar website has registered more than $700,000^{57}$ visits since its launch. The Sindh Education and Literacy Department partnered with SABAQ/MUSE ${ }^{58}$ a local digital-content provider to make teaching and learning content available to children, teachers and parents through distance-learning platforms.

On May 4, 2020 the Federal Ministry of Education and Professional Training announced Pakistan's National Education Response and Resilience Plan (K-12) for Covid-19 developed in a rapid consultative process (Ministry of Federal Education and Professional Training, 2020).

\section{Looking Ahead}

Pakistan's education sector is receptive and eager to test and trial EdTech solutions to advance learning outcomes in schools but many provinces have limited scope for setting up public-private partnerships in education. Further, although ICT-related legal provisions, policies, strategies and implementation frameworks introduced over the years by federal and provincial governments are helping to strengthen the ICT ecosystem, access to infrastructure, like computers and the internet, remains low and prohibitively expensive for most of the population. In the last five years, there has been a significant increase in local EdTech entrepreneurs, a positive and promising development for the country's education sector. However, the majority of these initiatives are pilot activities that have not yet reached scale and that require mentoring and financial resources to improve quality and better target tools and platforms to marginalised learners living in poverty and rural areas. The public education system also needs technical guidance and resources to leverage the available ICT options within the country and to adopt available open-distance learning resources from around the globe.

Going forward, it will be critical for the education sector to address these challenges and harness the full potential of educational technology, to eliminate learning poverty for all students in Pakistan.

\footnotetext{
${ }^{55}$ See: https://taleemghar.punjab.gov.pk/

${ }^{56}$ See: https://download.cnet.com/eLearn-App/3000-20414 4-77994256.html

${ }^{57}$ See: https://academiamag.com/taleem-ghar-delivering-education-in-the-safety-of-homes/

${ }^{58}$ See: https://sabaq.edu.pk/
} 


\section{Further reading}

Kaye. T., Groeneveld, C., Coflin, C.M., \& Hassler, B. (2020, May). Nepal “Ask me anything session": Responses to audience questions.

https://docs.edtechhub.org/lib/UXQG7GRG/download/46FZ7QTM/Kaye\%20et\% 20al 2020 Nepal\%20\%E2\%80\%9CAsk\%20me\%20anything\%E2\%80\%9D\%20Sess ion.pdf

Moss, C. (2020, January 24). 15 EdTech research papers that we share all the time. The EdTech Hub.

https://edtechhub.org/2020/01/24/15-edtech-research-papers-that-we-share-all -the-time/

Moss, C. (2020, January 22). 18 large-scale EdTech initiatives on our radar in 2020. The EdTech Hub.

https://edtechhub.org/2020/01/22/18-large-scale-edtech-initiatives-on-our-rada r-in-2020/

Trucano, M. (2013, July 08). 10 principles to consider when introducing ICTs into remote, low-income educational environments.

https://blogs.worldbank.org/edutech/10-principles-consider-when-introducing-i cts-remote-low-income-educational-environment

\section{References}

Aahung. (n.d.). Resources. Retrieved 21 July 2020, from https://www.aahung.org/resources

Aga Khan Development Network. (n.d.). Pakistan. Retrieved 20 July 2020, from https://www.akdn.org/where-we-work/south-asia/pakistan

Allama Iqbal Open University. (n.d.). Retrieved 21 July 2020, from https://www.aiou.edu.pk/

ASER. (2019). Academy for Education Planning and Management and Annual Status of Education Report.

Asian Development Bank. (2019). School Education in Pakistan: A Sector Assessment (0 ed.). Asian Development Bank. https://doi.org/10.22617/TCS190039

Conceição, P., \& United Nations Development Programme. (2019). Human development report 2019: Beyond income, beyond averages, beyond today: 
inequalities in human development in the 21 st century.

http://hdr.undp.org/sites/default/files/hdr2019.pdf

Developments in Literacy. (n.d.). Retrieved 20 July 2020, from https://www.dil.org

FESF. Family Educational Services Foundation. (2018). Technology Based Deaf

Education Initiative by FESF Pakistan Wins Prestigious WISE Awards.

https://www.fesf.org.pk/technology-based-deaf-education-initiative-by-fesf-paki stan-wins-prestigious-wise-awards/

Google. (n.d.). Read Along by Google: A fun reading app - Apps on Google Play.

Retrieved 21 July 2020, from

https://play.google.com/store/apps/details?id=com.google.android.apps.seekh \&hl=en

Government of Pakistan. Economic Adviser's Wing, Finance Division. (2019). Pakistan Economic Survey 2018-19. Government of Pakistan.

http://www.finance.gov.pk/survey/chapters 19/Economic Survey 2018 19.pdf

Government of Pakistan. Ministry of Federal Education and Professional Training. (n.d.). Retrieved 20 July 2020, from

http://mofept.gov.pk/ProjectDetail/MzkyNDc2MjMtY2VjYy00ZDA4LTk5OTUtNzU yNDI3ZWMzN2Rm

Government of Pakistan, Ministry of Federal Education and Professional Training, National Education Management Information System, \& Academy of Educational Planning and Management. (2018). Pakistan Education Statistics 2016-17.pdf.

http://library.aepam.edu.pk/Books/Pakistan\%20Education\%20Statistics\%20201 6-17.pdf

Government of Pakistan. Ministry of Information Technology \& Telecommunication, Government of Pakistan. (n.d.). Retrieved 20 July 2020, from https://moitt.gov.pk/

Government of Pakistan. Ministry of Interior and Narcotics Control. (n.d.). New Guidelines for the INGOs to work with NDMA / PDMAs in COVID 19 Crises. Retrieved 20 July 2020, from https://ingo.interior.gov.pk/

Government of Pakistan. Pakistan Bureau of Statistics, Government of Pakistan, \& Ministry of Planning Development \& Special Initiatives. (2020). Pakistan Social \& Living Standards Measurement Survey 2018-19 (p. 40). Government of Pakistan. 
Government of Sindh. (n.d.). School Education and Literacy Department. Retrieved 20 July 2020, from http://www.sindheducation.gov.pk/

Government of Sindh. Information Technology Department Government of Sindh. (n.d.). Retrieved 20 July 2020, from https://istd.sindh.gov.pk/about

Government of Sindh. School Education \& Literacy Department. (2019). School Education Sector Plan and Roadmap for Sindh (2019-2024).

https://www.globalpartnership.org/sites/default/files/document/file/2020-19-P akistan-Sindh-ESP.pdf

Government of the Punjab. (2018). Punjab IT Policy.

https://policy.pitb.gov.pk/system/files/Punjab IT Policy 2018 05062018.pdf

Government of the Punjab. (2019). Punjab Education Sector Plan 2019/20-2023/2024. https://www.globalpartnership.org/sites/default/files/document/file/2020-19-P akistan-Punjab-ESP.pdf

Government of the Punjab. (2020). Taleem Ghar. https://taleemghar.punjab.gov.pk/

Government of the Punjab. Punjab Information Technology Board,. (n.d.). Retrieved 20 July 2020, from https://www.pitb.gov.pk/

Government of the Punjab. School Education Department. (n.d.). Retrieved 20 July 2020, from https://schools.punjab.gov.pk/

Human Rights Watch. (2017, December 13). World Report 2018.

https://www.hrw.org/world-report/2018

Idara-e-Taleem-o-Aagahi. (n.d.). Retrieved 20 July 2020, from http://itacec.org/

IIm Ideas 2, Cambridge Education. (n.d.). Building the pipeline for entrepreneurs who are 'wired to progress'. Retrieved 20 July 2020, from

https://www.camb-ed.com/article/241/ilm-ideas-2

ILMA. (n.d.). Retrieved 21 July 2020, from http://ilma.sabaq.edu.pk/

Invest2Innovate. (n.d.). Retrieved 21 July 2020, from

https://invest2innovate.com/incubate/

Jazz Foundation. (n.d.). Education. Retrieved 21 July 2020, from http://www.jazzfoundation.com.pk/our-program/education/

KarMuqabla. (n.d.). Education and distance learning gaming platform. Retrieved 21 July 2020, from https://www.karmuqabla.com/ 
Knowledge Platform. (n.d.). Retrieved 21 July 2020, from

https://www.knowledgeplatform.com/

Ministry of Education. (2009). National Education Policy 2009. Government of Pakistan.

http://itacec.org/document/2015/7/National Education Policy 2009.pdf

Ministry of Education, \& Education Sector Reform Assistance (ESRA) Program. (2010). National Information and Communications Strategy for Education in Pakistan, 2004-2005. Government of Pakistan.

https://www.scribd.com/document/30166522/NICT-Strategy-for-Education-in-P akistan

Ministry of Federal Education and Professional Training. (2018). National Education Policy Framework 2018. Government of Pakistan.

http://mofept.gov.pk/Sitelmage/Policy/National\%20Eductaion\%20Policy\%20Fra mework\%202018\%20Final.pdf

Ministry of Federal Education and Professional Training. (2020). Pakistan National Education Response Resilience Plan (K-12) for Covid-19. Government of Pakistan. https://planipolis.iiep.unesco.org/sites/planipolis/files/ressources/pakistan nati onal education response resilience plan covid-19.pdf

Ministry of IT \& Telecom. (2018). Digital Pakistan Policy. Government of Pakistan. https://moitt.gov.pk/Sitelmage/Misc/files/DIGITAL\%20PAKISTAN\%20POLICY.pdf

Ministry of Planning, Development and Reform. Planning Commission. (2014). Pakistan 2025: One Nation - One Vision. Government of Pakistan. https://www.pc.gov.pk/uploads/vision2025/Pakistan-Vision-2025.pdf

National Incubation Center. (n.d.). Retrieved 21 July 2020, from http://nicpakistan.pk/

National Institute of Population Studies. (2019). Pakistan Demographic and Health Survey, 2017-18. https://dhsprogram.com/pubs/pdf/FR354/FR354.pdf

Naviwala, N. (2016). Pakistan's Education Crisis: The Real Story (p. 44). Wilson Center.

Naviwala, N. (2017, October 18). Pakistan uses regulations to tighten grip on INGOs. Devex.

https://www.devex.com/news/sponsored/pakistan-uses-regulations-to-tightengrip-on-ingos-91003

Okeleke, K. (2019). The Power of Mobile to Accelerate Digital Transformation in Pakistan. GSMA. 
https://www.gsma.com/mobilefordevelopment/wp-content/uploads/2020/06/T he-Power-of-Mobile-to-Accelerate-Digital-Transformation-in-Pakistan-2019.pdf

Orenda Project. (n.d.). Taleemabad. Retrieved 21 July 2020, from

http://www.orendaproject.org/

Pakistan Telecommunication Authority. (2019a). Annual Report 2019.

https://www.pta.gov.pk/assets/media/pta ann rep 2019 27032020.pdf

Pakistan Telecommunication Authority. (2019b). Telecom Indicators | PTA.

https://www.pta.gov.pk/en/telecom-indicators

Punjab IT Board. (n.d.). ELearn App for Android. Download.Com. Retrieved 23 July 2020, from

https://download.cnet.com/eLearn-App/3000-20414 4-77994256.html

Read Foundation. (n.d.). Retrieved 20 July 2020, from

http://www.readfoundation.org/

Right To Education: Pakistan. (n.d.). Retrieved 23 July 2020, from

https://rtepakistan.org/about-rte-pakistan/

SABAQ. (n.d.). Pakistan's Award-winning Learning Apps for Kids. Retrieved 20 July 2020, from https://sabaq.edu.pk/

Sabaq Foundation. (n.d.). Free Videos \& Tests, Grades K-12, Pakistan. Retrieved 20 July 2020, from https://sabaq.pk

Schwab, K. (2019). The Global Competitiveness Report 2019 (p. 666). World Economic Forum.http://www3.weforum.org/docs/WEF TheGlobalCompetitivenessReport 2019.pdf

Siddique, R. (2018). Educating 21,000+ Children Through the SABAQ Initiative (p. 19). SABAQ.

Sindh Education Foundation, Government of Sindh. (n.d.). Introducing Smart Teaching and Learning (INSTAL). Retrieved 20 July 2020, from https://www.sef.org.pk/introducing-smart-teaching-and-learninginstal/

TCF - The Citizens Foundation. (2018, December 27). https://www.tcf.org.pk/

Teleschool Inauguration 13-04-2020.jpg. (n.d.). Retrieved 21 July 2020, from http://mofept.gov.pk/Sitelmage/Misc/images/Teleschool\%20Inuguration\%201304-2020.jpg 


\section{\#EdTechHub}

TeleTaleem. (n.d.). Welcome to TeleTaleem. Retrieved 21 July 2020, from https://www.teletaleem.com/

The Academia. (2020, May 12). Taleem Ghar: Delivering Education In The Safety Of Homes.

https://academiamag.com/taleem-ghar-delivering-education-in-the-safety-of-h omes/

The Economist. (2018). Pakistan is home to the most frenetic education reforms in the world.

https://www.economist.com/briefing/2018/01/04/pakistan-is-home-to-the-most -frenetic-education-reforms-in-the-world

ToffeeTV. (n.d.). ToffeeTV. Retrieved 21 July 2020, from https://toffeetv.com/about/

Tufts University. (n.d.). Lahore University of Management Sciences, Pakistan. The Talloires Network. Retrieved 21 July 2020, from

https://talloiresnetwork.tufts.edu/lahore-university-of-management-sciences-p akistan-2/

USAID. (n.d.). Reading Learning Material | USAID-funded Pakistan Reading Project. Retrieved 21 July 2020, from: http://www.pakreading.org.pk/resources/publications/reading-learning-materia !

Virtual University of Pakistan. (n.d.). Retrieved 21 July 2020, from http://www.vu.edu.pk/AboutUs/AboutVU.aspx

WonderTree. (n.d.). Retrieved 21 July 2020, from https://wondertree.co/about/ World Bank. (2019). Learning Poverty Brief (p. 10). http://pubdocs.worldbank.org/en/843181571223525631/SAS-LPBRIEF.pdf 